\title{
G Protein-Coupled Receptor Kinase
}

National Cancer Institute

\section{Source}

National Cancer Institute. G Protein-Coupled Receptor Kinase. NCI Thesaurus. Code C26233.

G protein-coupled receptor kinases regulate G protein-coupled receptors through phosphorylation. 